\title{
EFFECTS OF APPLICATION OF COCONUT HUSK AND COIR DUST ON THE YIELD OF COCONUT
}

\author{
M. DE S. LIYANAGE, K. S. JAYASEKARA and M. N. FERNANDOPULLE \\ Coconut Research Institute of Sri Lanka.
}

\section{INTRODUCTION}

It is widely recognized that the coconut palm (Cocos nucifera $\mathrm{L}$.) requires a regular supply of water for maintaining a consistent production throughout the year (Thampan, 1975). In the intermediate dry zone $1600 \mathrm{~mm}$ per year) and dry. zone (1250 mm per year) of the "Coconut Triangle" where rainfall is not well distributed with recurring droughts, palms are often subjected to periodic moisture deficit during the dry season, causing a setback in the growth of young palms and, reducing the yield of bearing palms. The reduced rainfall experienced during the recent has aggravated this situation, resulting in more frequent and prolonged droughts. For example, it is reported that the local production of coconut declined by about $25 \%$ in 1987 as compared with 1986 (Coconut Development Authority, 1987), which could be attributed largely to the drought effects in 1986. Furthermore, Abeywardane (1979) reported that the coconut production in dry areas could be increased considerably by supplying water to the palm during dry periods. However, availability of water is a major limiting factor during the dry season, particularly in dry areas. Therefore, conservation of soil moisture has become an important practice in the management of coconut plantations under rainfed conditions, particularly in the intermediate and dry zones of Sri Lanka.

Traditionally, coconut husk is buried in pits to conserve soil moisture for the palm. However, little attempt has been made so far to quantify its beneficial effects on coconut yield. Furthermore, the use of coir dust (dust remaining after extraction of fibre from the coconut husk) for this purpose 
has been restricted in the past, mainly because of its low nutrient value (Santhirasegarm, 1965), without considering its moisture conserving ability. The moisture conservation ability of coconut husk and coir dust in different soil types is another aspect which has not been investigated. Therefore, two experiments were conducted to compare the relative effects of coconut husk and coir dust in mature coconut plantations established on (two major soil types) lateritic and sandy soils.

\section{MATERIALS AND METHODS}

Experiment 1: Study the effect of coconut husk and coir dust on coconut yield in lateritic gravel soil.

This experiment was commenced in 1981 at Ratmalagara Estate, Madampe in a 34 - year old coconut plantation with a density of $138 \mathrm{palms} / \mathrm{ha}$. The soil at the experimental site is lateritic gravel (ultisol) with a mean annual rainfall of $1500 \mathrm{~mm}$. Coconut palms were regularly fertilized with $3.0 \mathrm{~kg} / \mathrm{palm} / \mathrm{year}$ of inorganic fertilizer mixture $(14.0-9.6-20.9)$.

The three treatments were : $\left(T_{1}\right)$ control - no treatment, $\left(T_{2}\right)$ Coconut husks arranged in layers in pits of $3.0 \mathrm{~m}$ length $\times 1.2 \mathrm{~m}$ width $\times 0.45 \mathrm{~m}$ depth located along the row between two palms and $\left(\mathrm{T}_{3}\right)$. Coir dust placed in layers in pits of similar dimensions and location. These treatments were replicated seven times in a fully randomized design, with six effective palms per plot. Each pit consists of either three layers of coconut husk or four layers of coir dust, each layer being alternated with a soil layer about $5 \mathrm{~cm}$ thick. The balance soil was heaped on top. Each pit of this size would require either about 400 husks or about 20 baskets of coir dust to fill up to the ground level.

The number of nuts and copra weight per palm were recorded bimonthly each year from 1984 to 1986. Data prior to 1984 were not considered as only the number of nuts per palm was recorded and thus incomplete. Soil moisture was measured during the dry period of each year from samples drawn adjacent to pits at 0-30 cm depth. In the sixth year, few husk and coir dust pits were selected at random to study the changes in physical and chemical properties of soil. For this purpose soil samples or measurements taken from three pits of each treatment were bulked together for analysis. Available water in soil was detemined using a pressure plate apparatus. Bulk density of soil was measured using the core sampling method and the total porosity was also calculated. Soil pH (1:5 water suspension) was determined following the method of Black (1965). Total nitrogen in soil was estimated by Kjeldahal method and organic carbon by using walkley and Black method.

Finally, roots in pits were exposed by washing using a power sprayer, and the number of roots per $\mathrm{m} 2$ was counted along the vertical plane and their dry weights determined for each treatment.

Experiment 2 : Study the effect of different methods of placement of coconut husks and coir dust on coconüt yield.

This experiment was commenced in 1982 at Shantil Estate, Pallama on a 50-year old coconut plantation with a density of $138 \mathrm{palms} / \mathrm{ha}$. The soil at the experimental site was deep sand (regosol) with a mean annual rainfall of $1400 \mathrm{~mm}$. Coconut palms were regularly fertilized with 4 to $5 \mathrm{~kg} /$ palm/year of inorganic fertilizer mixture (7.5:8.0:18.0).

The five treatments were : $\left(T_{1}\right)$ control - no treatment $\left(T_{2}\right)$ Coconut husks in pits of $3 \mathrm{~m}$ length $x 1.8 \mathrm{~m}$ width $\times 0.45 \mathrm{~m}$ depth located along the row between two palms, $\left(\mathrm{T}_{3}\right)$ Coconut husks in 
circular trenches of $0.45 \mathrm{~m}$ wide and $0.45 \mathrm{~m}$ deep around each palm, $2 \mathrm{~m}$ away from its base, $\left(T_{4}\right)$ Coir dust in circular trenches of similar dimensions and location as in T3. These treatments were arranged in a randomized block design with five replicates, consisting of 12 effective palms per plot.

Both pits and circular trenches had almost identical volume ( 2.12 and $2.10 \mathrm{cu} . \mathrm{m}$, respectively) and therefore each of such pits or trenches required either about 550 husks or about 25 baskets of coir dust to fill up to the ground level, and the balance soil was heaped on top. In each plot, there were either 15 pits or 12 trenches so that the volume of pits and trenches per plot was 31.9 and 25.2 Cu. m. respectively.

Records and measurements were taken in the same manner as described in Experiment 1. Here again yield records prior to 1984 were not considered as they were incomplete.

At both locations, the annual rainfall and the number of rainy days were recorded from 1983 to 1986 (Table 1).

Table 1 Rainfall data at the Experimental Sites

\begin{tabular}{lrrrrrr}
\hline & \multicolumn{3}{c}{ Ratmalagara } & \multicolumn{3}{c}{ Shantil } \\
& 1983 & 1984 & 1985 & 1983 & 1987 & 1985 \\
\hline Rainfall/year (mm) & 1035.2 & 2394.2 & 1483.5 & 1208.9 & 2389.1 & 1304.6 \\
No. of rainy days & 116 & 137 & 110 & 105 & 134 & 110 \\
\hline
\end{tabular}

\section{RESULTS}

Coconut and copra yield : Results in Table 2 showed that both coconut husk and coir dust induced a significant $(\mathrm{p}=0.05)$ increase in nut yield in lateritic soil and palms gave $15-20 \%$ higher yield than the control. In contrast, a significant improvement in copra yield per palm was found only in plots treated with coir dust pits. Furthermore, mean yield increase in palms due to husk and coir dust treatments did not differ markedly in lateritic soil. The results on the effect of different placement of husk and coir dust on the yield of coconut in sandy soil (Table 3) showed that the placement of husk in pits and trenches as coir dust pits caused a significant increase in nut yield of palms over the control. In contrast, placement of husk in pits was the only treatment that caused a significant improvement in copra yield in sandy soils. Furthermore, placement of coir dust in trenches had the least effect on the yield of palms. 
Table 2 Effect of Coconut husk and coir dust on the yield of Coconut in Lateritic gravel soil

2a: Yield in terms of nuts/palm

2b: Yield in terms of copra $(\mathrm{kg} / \mathrm{palm})$

\begin{tabular}{|c|c|c|c|c|c|c|c|c|}
\hline \multirow{2}{*}{ Treatments } & \multicolumn{4}{|c|}{ Year } & \multicolumn{4}{|c|}{ Year } \\
\hline & 1984 & 1985 & 1986 & Mean & 1984 & 1985 & 1986 & Mean \\
\hline Control & 50.8 & 60.0 & 72.9 & 61.2 & 10.30 & 13.82 & 14.52 & 12.88 \\
\hline Husk pits & 58.3 & 70.5 & 83.2 & $\begin{array}{l}70.7 \\
(15.5 \%)\end{array}$ & 10.58 & 16.18 & 14.87 & $\begin{array}{l}13.86 \\
(7.6 \%)\end{array}$ \\
\hline Coir dust pits & 58.8 & 72.8 & 90.9 & $\begin{array}{c}74.2 \\
(20.6 \%)\end{array}$ & 10.95 & 17.30 & 16.22 & $\begin{array}{l}14.82 \\
(15.1 \%)\end{array}$ \\
\hline Significance & $*$ & $*$ & $*$ & $*$ & n.s. & * & $*$ & * \\
\hline $\operatorname{LSD}(\mathrm{P}=0.05)$ & 7.8 & 11.9 & 8.3 & 7.6 & - & 2.55 & 1.89 & 1.48 \\
\hline $\mathrm{CV}(\%)$ & 12.5 & 15.3 & 7.8 & 9.3 & 12.9 & 13.9 & 10.8 & 8.68 \\
\hline
\end{tabular}

Figures in parenthesis indicate \% increase over control

n.s. $=$ not significant

At both locations there was a sharp drop in nut and copra yield of palms in 1984 compared with 1985, irrespective of the treatments. The rainfall data (Table 1) showed that in terms of the total rainfall, 1983 is a 'bad year' compared with 1984, which is considered as a 'good year'. Despite the unfavorable weather conditions experienced in 1983, nut yield of palms treated with husk and coir dust in pits showed a significant improvement over the untreated control plots in 1984 at both locations (Tables 2 and 3). A similar situation occurred in sandy soil following low rainfall in 1985, which resulted in a drop in both nut and copra yield in 1986, irrespective of treatments (Table 3). Here again the benefit of husk pits over control was evident.

Soil moisture conservation : Data on the effect of coconut husk and coir dust pits on moisture conservation in gravelly and sandy soil are given in Table 4. According to these results, soil drawn from husk and coir dust treatments retained a higher moisture content during the dry period, compared with that in control plots. In lateritic soil, moisture content ranged between $3.4-3.7 \%$ in husk and coir dust pits, compared with $3.0 \%$ in control plots.

Similarly, retention of moisture in sandy soil was markedly improved during the dry period due to the placement of husk in pits or trenches. 
Table 3 Effect of Different Placement of Coconut Husk and Coir dust on the yield of coconut in Sandy Soil

3a: Yield in terms of nuts/palm

3b: Yield in terms of copra $(\mathrm{Kg} / \mathrm{palm})$

\begin{tabular}{|c|c|c|c|c|c|c|c|c|}
\hline \multirow{2}{*}{ Treatments } & \multicolumn{4}{|c|}{ Year } & \multicolumn{4}{|c|}{ Year } \\
\hline & 1984 & 1985 & 1986 & Mean & 1984 & 1985 & 1986 & Mean \\
\hline Control & 44.9 & 84.8 & 47.2 & 58.9 & 13.41 & 20.61 & 8.57 & 14.20 \\
\hline Husk pits & 56.3 & 98.7 & 56.5 & $\begin{array}{l}70.5 \\
(19.7 \%)\end{array}$ & 16.35 & 23.12 & 10.28 & $\begin{array}{l}16.58 \\
(16.8 \%)\end{array}$ \\
\hline Husk trenches & 55.0 & 95.6 & 55.3 & $\begin{array}{l}68.6 \\
(16.5 \%)\end{array}$ & 15.92 & 22.51 & 9.95 & $\begin{array}{l}16.13 \\
(13.6 \%)\end{array}$ \\
\hline Coir dust pits & 55.6 & 94.7 & 54.8 & $\begin{array}{l}68.4 \\
(16.1 \%)\end{array}$ & 13.62 & 22.76 & 8.81 & $\begin{array}{l}15.10 \\
(16.3 \%)\end{array}$ \\
\hline $\begin{array}{l}\text { Coir dust } \\
\text { trenches }\end{array}$ & 52.5 & 93.3 & 53.5 & $\begin{array}{l}66.4 \\
(12.7 \%)\end{array}$ & 12.12 & 21.94 & 8.26 & $\begin{array}{l}14.11 \\
(-1.34 \%)\end{array}$ \\
\hline Significance & $*$ & $\$$ & $\%$ & * & n.s. & $\%$ & 6 & $\%$ \\
\hline $\operatorname{LSD}(\mathrm{P}=0.05)$ & 9.8 & 8.4 & 7.6 & 9.3 & - & 2.44 & 1.38 & 2.04 \\
\hline $\mathrm{CV}(\%)$ & 16.7 & 6.4 & 15.9 & 9.9 & 29.8 & 8.2 & 28.0 & 13.21 \\
\hline
\end{tabular}

Figures in parenthesis indicate \% increase or decrease (-) over control n.s. = not significant

Table 4 Effect of Coconut Husk and coir dust on Moisture content of the soil

\begin{tabular}{lllll}
\hline \multicolumn{1}{c}{ Treatments } & \multicolumn{3}{c}{ Soil moisture (\% dry weight) } \\
\cline { 2 - 5 } & 1984 & 1985 & 1986 & Mean \\
\hline LATERITIC SOIL & & & & \\
& & & & \\
Control & 3.96 & 3.73 & 1.30 & 2.99 \\
Husk pits & 4.05 & 4.44 & 1.65 & 3.38 \\
Coir dust pits & 4.72 & 4.68 & 1.75 & 3.72 \\
& & & & \\
SANDY SOIL & & & & \\
& & & & \\
Control & 2.12 & 2.46 & 2.66 & 2.41 \\
Husk pits & 3.74 & 4.00 & 3.65 & 3.80 \\
Husk trenches & 3.50 & 3.16 & 3.31 & 3.32 \\
Coir dust pits & 3.32 & 3.51 & 3.09 & 3.31 \\
Coir dust trenches & 2.61 & 2.79 & 2.7 & 2.72 \\
\hline
\end{tabular}


Soil properties : Data on the effects of coconut husk and coir dust pits on physical and chemical properties of gravelly and sandy soil (Table 5) measured six years later, indicated that there was substantial improvement in available water, porosity, organic carbon and soil nitrogen, while bulk density of soil was reduced due to husk and coir dust over the control, irrespective of the soil type. However, soil $\mathrm{pH}$ remained unchanged due to husk and coir dust pits compared with control, in both soil types.

Table 5 Effect of Coconut Husk and coir dust on Physical and Chemical Properties

\begin{tabular}{lcccccc}
\hline & $\begin{array}{c}\text { Available } \\
\text { water } \\
(\%)\end{array}$ & $\begin{array}{c}\text { Porosity } \\
(\%)\end{array}$ & $\begin{array}{c}\mathrm{BD} \\
(\mathrm{g} / \mathrm{cc})\end{array}$ & $\begin{array}{c}\mathrm{OC} \\
(\%)\end{array}$ & $\mathrm{pH}$ & $\begin{array}{c}\mathrm{N} \\
(\mathrm{ppm})\end{array}$ \\
\hline LATERITIC SOIL & & & & & & \\
& & & & & & \\
Control & 2.7 & 38.2 & 1.55 & 0.23 & 5.1 & 654.0 \\
Husk pits & 4.3 & 52.0 & 1.36 & 0.61 & 5.1 & 719.0 \\
Coir dust pits & 8.5 & 58.0 & 1.18 & 1.56 & 5.0 & 523.0 \\
SANDY SOIL & & & & & & \\
& & & & & & \\
Control & 1.91 & 40.7 & 1.50 & 0.22 & 5.3 & 458.0 \\
Husk pits & 3.41 & 62.4 & 1.13 & 0.58 & 5.3 & 654.0 \\
Coir dust pits & 4.35 & 48.9 & 1.35 & 0.73 & 5.6 & 654.0 \\
\hline
\end{tabular}

$\mathrm{BD}=$ Bulk Density $\quad \mathrm{OC}=$ Organic Carbon

In gravelly soil, coir dust pits retained more water and increased total porosity, organic carbon and caused marked reduction in bulk density and soil nitrogen than husk pits (Table 5). In contrast effects of husk and coir dust on physical and chemical properties in sandy soil were rather inconsistent. Whilst coir dust caused a higher increase in available water and organic carbon content than husk in sandy soil, the increase in soil porosity and the decrease in bulk density was more prominent due to husk than coir dust, as shown in Table 5. Furthermore, there was no change in the nitrogen content of sandy soil due to husk and coir dust.

Root regeneration : In both soil types, husk and coir dust pits encouraged root regeneration in the palm (Table 6). However, in gravelly soil, both number and weight of roots regenerated in coir dust pits were greater than in husk pits after six years. The reverse trend was true in sandy soil where the number and weight of roots per unit area were higher in husk pits than in coir dust pits (Table 6).

Table 6 Effect of Coconut husk and coir dust on root regeneration

$\begin{array}{lll}\text { Treatments } & \text { No. of roots } / \mathrm{m} 2 \quad \text { Root dry weight }(\mathrm{g} / \mathrm{m} 2)\end{array}$

LATERITIC SOIL

$\begin{array}{lcc}\text { Control } & 144 & 246.68 \\ \text { Husk pits } & 185 & 635.22 \\ \text { Coir dust pits } & 220 & 898.38 \\ & & \\ \text { Con SOIL } & 143 & 380.07 \\ \text { Husk pits } & 188 & 492.12 \\ \text { Coir dust pits } & 166 & 420.59\end{array}$




\section{DISCUSSION AND CONCLUSIONS}

The results of this study indicated that both husk and coir dust exerted a substantial improvement in nut yield in lateritic soil. In contrast, the copra yield of palms was increased only in plots treated with coir dust pits, which suggests that coir dust could be more effective than husk for increasing copra production. In sandy soil, placement of husk in pits caused a substantial improvement in nut and copra yield, while placement of husk or coir dust in circular trenches was least effective.

It is well known that the yield of palms in a particular year is a reflection of weather conditions, primarily total rainfall and its distribution, in the previous year. In this study, the low rainfall in 1983 has reduced the yield of paims in 1984 at both locations. However, it is evident from the data that palms in plots treated with husk and coir dust maintained a higher nut yield than those in control plots in gravelly soil. Whereas in sandy soil, placement of husk in pits showed a better yield response than in trenches. This could be partly explained by the fact that the total volume of pits in each plot was higher than the trenches, so that there would be more husk in pits per plot than in trenches per plot.

The study demonstrated an increase in nut yield with husk or coir dust treatments in both 'good' and 'bad' years. This could be due partly to the ability of husk and coir dust, to absorb and retain moisture during the rainy season which is made available to the palm during the dry period. Child (1964) also reported that coir dust improved the retention of moisture in gravelly soil. Further, improvement in soil physical structure due to husk and coir dust, may have promoted greater root regeneration in pits, which could in turn improve the moisture absorbing capacily of the palm. This is an additional advantage in the use of husk and coir dust in coconut lands.

From these results, it can be concluded that use of husk and coir dust in pits is beneficial to coconut palms, especially in the Dry and Intermediate Zones subjected to periodic drought. Furthermore, use of coir dust in pits could be recommended as an effective alternative to husk for moisture conservation in coconut lands, particularly in areas where husks can be marketed easily for the coir industry.

The benefit/cost ratio at $18 \%$ discount rate for laying down husk pits in sandy soil and coir dust pits in lateritic soil, provided materials are available at the site is estimated at 3.85 and 4.26 , respectively. (Fernando, pers. comm.) This suggests that these two moisture conservation practices are economically viable.

\section{ACKNOWLEDGEMENTS}

The authors wish to express their gratitude to the Director, Coconut Research Institute of Sri Lanka for providing facilities, to Dr. P. Loganathan, former Soil Chemist for planning the experiments, to Mr. D. T. Mathes, Senior Biometrician for statistical advice and to the technical and field staff of Soils and Plant Nutrition and Agronomy Divisions, for assistance in conducting the experiments. 


\section{REFERENCES}

Abeywardane, V (1979). Influence of watering on the yield of coconut. Ceylon Cocon. Q., 30, $91-100$.

Black, C A (1965). Methods of soil analysis, part 2. American Society of agronomy monograph No. 9, Madison, Wisconsion, USA.

Child, R (1964), Coconuts. Longmans, London. pp 216.

Coconut Development Authority (1987). Sri Lanka Coconut Statistics, Ministry of Coconut Industries, Colombo, $\mathrm{p} 4$.

Santhirasegaram, S (1965). Dry dust from coconut fibre mill. A useful soil ameliorant. Ceylon Cocon. Q., 16, 85 - 98.

Thampan, P K. (1978). The coconut palm its products. pp 19 - 142 Green Ville Publishing House, India. 